\title{
The Pragmatic Presuppositions of 'somebody/someone' in Christian Religious Discourse in Nigeria
}

\author{
Samuel Ayodele Dada \\ Department of English and Literary Studies \\ Ekiti State University \\ Ado- Ekiti, Nigeria \\ Omoregbe Esohe Mercy \\ Department of Linguistics and African Languages \\ University of Benin \\ Benin City, Nigeria
}

\section{Abstract}

The study examines the pragmatic presuppositions of 'somebody' and 'someone' as being employed by preachers in Christian ministration discourse in Nigeria. The study aims at investigating the pragmatic motivations behind the use of these pronouns in Churches by preachers. The study identifies the necessity of the context of situation as the major reason behind the use of these pronouns. Indeed, 'somebody is here ...' is the language of God to His people in such an occasion. The study has once more brought to the fore the merit of the campaign that a writer/speaker needs good training not only in the grammatical competence but also in the communicative competence of the language with which he operates.

Keywords: Christianity; language use; pragmatics; presupposition; somebody; someone.

\section{Council for Innovative Research}

Peer Review Research Publishing System

Journal: Journal of Advances in Linguistics

Vol 2, No.2

editor@cirworld.com

www.cirworld.com, member.cirworld.com 


\section{Introduction}

'Somebody/someone' is in the category of Person Deixis in English. The English language is the mother tongue of the British people. Its incursion into West Africa was thus a momentous, historical incidence which exerted tremendous influence on relation as well as linguistic situation in the region. English language incursion into Nigeria coincided with the onset of British activities on the West African coast. The British came into Nigeria for a number of reasons. The implantation of English in Nigeria followed three channels namely: commerce, Christian mission and colonial rule. The missionary activities were particularly significant in the development and propagation of the language. Thus, the language became the language of evangelism and the language of Western education in Nigeria.

To be sure, any word of English has a chance of occurring in a religious discourse in English. In other words, if religion is a way of life, then any aspect of life can be the subject of sermon in religious settings. Thus, the preacher/pastor is in a position to freely draw from the lexicon of English. However, we observe that certain words, including religious slangs and colloquialisms, tend to occur frequently in Christian religious discourse in Nigeria and even the world over. These invariably have given the church in this dispensation her own vocabulary. In this paper, we examine two of such words, 'somebody' and 'someone', illustrating their typical uses with their pragmatic presuppositions in Christian religious gatherings (Pentecostal or Orthodox) in Nigeria and globally.

A growing body of linguistic research on Pronoun usage in socio-cultural contexts include: Brown and Gilman, 1968; Brown and Ford, 1961; Adetugbo, 1969; Paulston, 1975; Halliday and Hasan, 1976; Lambert and Tucker, 1976; Ekundayo, 1977; Akinnaso,1980; Akindele,1990; Abiodun, 1992, 1999; Oha, 1994; Oyetade,1995; Adegoju, 2001, 2002; Ikotun, 2003, 2009, 2010a, 2010b. The major focus of these past studies is the personal pronouns and they depict that the major function of these pronouns in texts or discourse is that of a cohesive device. Out of the list above, the only research work which delves into the pragmatic aspects of the use of the indefinite pronouns 'somebody' and 'someone' in Christian ministration discourse is that of Adegoju (2002).

Adegoju's (2002) findings point to these as mere devices used by ministers to generate and sustain audience involvement in the course of their ministrations. To Adegoju, these pronouns are used to create and sustain excitement in Pentecostal churches. Thus, this view identifies the use of these pronouns in Pentecostal gatherings as a negative activity embarked upon by preachers to arrest the attention of the congregation and to capitalize on their anxiety. While it is true that fake preachers/prophets deployed for use these pronouns during church services for self-seeking purpose, that is, 'to maximize the response of the congretation'p.31. The fact remains that God's appointed ministers use these pronouns for some altruistic purposes as made evident in this study.

\section{Semantic versus Pragmatic Interpretation}

Utterances can be decoded based on their pragmatic, semantic, morphosyntactic and phonological compositions. Semantics adopts a formalist approach to the analysis of discourse whereas pragmatics requires a functionalist approach. Semantics according to Leech and Thomas (1990) deals with meaning as a dyadic relation between a form and its meaning whereas pragmatics has to do with meaning as a triadic relation - the relation that holds among the form, meaning and context. Linguistic semantics aims to account for what is linguistically encoded, while a pragmatic theory will explain how more detailed interpretations are derived on the basis of semantic representations.

Stalnaker (1972) defines pragmatics as 'the study of linguistic acts and contexts in which they are performed.' Kempson (1975) says 'pragmatics refers to the study of sentences in use.' Levinson (1983:9) defines pragmatics as 'the study of those relations between language and context that are grammaticalized, or encoded in the structure of language.' Yule (1996:1) says pragmatics is 'the study of meaning as communicated by a speaker (or writer) and interpretated by a hearer (or listener). According to Mey (2001:6) 'pragmatics studies the use of language in human communication as determined by the conditions of society.' Low (2003:1) is of the view that 'pragmatics is premised on the belief that context plays a role in what choices are made in encoding and decoding messages.' Evans and Green (2006: 160) opine that pragmatics is a necessary tool in analyzing meaning because 'words do not represent neatly packaged bundles of meaning but serves as points of access to vast repertoires of knowledge relating to a particular conceptual domain.'

For instance, except contextual knowledge is employed by a hearer 'the tea is really cold' may not be clearly understood as a complaint when such tea is served on a cold morning but a compliment when offered on a hot afternoon. Wisniewski (2007:1) throws more light on pragmatics by saying that:

Pragmatics is the study of meaning of words, phrases and full sentences, but unlike semantics which deals with the objective meanings of words that can be found in dictionaries, pragmatics is more concerned with the meanings that words in fact convey when they are used, or with intended speaker meaning as it is sometimes referred to. It can be said that pragmatics attempts to analyze how it happens that often more is communicated than said ... pragmatics examines the devices used by language users (ex. deictic expressions, or anaphora) in order to express the desired meaning and how it is perceived.

In what follows, the pragmatics devices used by language users shall be our focus. Before then, however, we provide Sperber and Wilson's (1981:281) explanation of these devices in order to have a full picture. They see pragmatics as:

The theory of utterance - interpretation ... the main aim of pragmatic theory is to provide an explicit account of how human beings interpret utterances. To do this, one would have to say how disambiguation is achieved; how reference is 
assigned; how sentence fragments are interpreted; how ungrammatical utterances are dealt with; what role presuppositional phenomena play; how implicatures (intended inferences) are worked out; how contextual and encyclopaedic knowledge is brought to bear and so on ...

As evident in the two excerpts above, the devices or pragmatic frameworks to be explored presently here, in respect of our data analysis include: context, deictic expressions, inferences, presuppositions, and implicatures. Others include: speech acts, face maintenance (FM), and mutual contextual beliefs (MCBs). These concepts will be deployed for use to exhume the pragmatic meaning of these pronouns within a particular context.

\section{Context}

A text normally occurs in a context. According to Halliday and Hassan (1976):

... there is a text and there is other text that accompanies it: text that is 'with', namely the context. This notion of what is 'with the text', however, goes beyond what is said and written: it includes other non-verbal goings- on - the total environment in which a text unfolds ...

Context of situation therefore refers to all the ongoing activities and the physical environment which are non-linguistic. In other words, it could be referred to as knowledge of the world. This type of knowledge is acquired by man through acculturation, observation, and personal experience of different socio-cultural and socio-linguistic events. Knowledge of the world most often serves as lubricant on which the smooth running of the wheels of communication revolves. The stronger the world knowledge of the interlocutors, the better and smoother the encoding and decoding process becomes. Expatiating further on this, Lawal (2003:153) presents a 'model of the aspects of a pragmatic theory.' Lawal's model identifies six hierarchical contexts of an utterance: linguistic, situational, psychological, social, sociological and cosmological. The linguistic context is language itself. The situational context refers to the topic of discourse plus the factors of the physical event including concrete objects, person and location. The psychological context is the background of the mood, attitudes and personal beliefs of the language user. The social context has to do with the interpersonal relations among the interlocutors. The sociological context is concerned with the socio-cultural and historical setting. The cosmological which has to do with the ultimate context covers the language user's world-view. The different contexts/competencies enunciated above form the bed- rock of this analysis.

\section{Deictic expressions}

Deixies is a word of Greek origin meaning 'to point'. The study of deixies underpins the belief that there are certain groups of words that are employed for linguistic pointing. According to Yule (1996:99):

Some words in the language cannot be interpreted at all unless the physical context,

especially the physica context of the speaker is known ... words like here, there, this, that. ... now, then, yesterday as well as most pronouns, such as I, you, him, her, them. Some sentences of English are virtually impossible to understand if we don't know who is speaking, about whom, where and when.

Deixies when removed from its situational context becomes completely vague. What is more, deitic expressions can only be understood in terms of speaker's intended meaning. According to Griffiths (2006:83) these categories of words 'in literature perform the action of further indicating the notion that we actually perform actions with language.' Levinson (2002:54) says, 'the study of deictic expressions is the most important approach available to language researchers in their bid to ascertain the relevance of context of language.' Yule (1999: 30) explains that deictic expressions help language users in referring because 'humans not language refer.' Invariably, if humans refer and not language it therefore means that intended speaker meaning is indispensable to pragmatic interpretation. The decoder must not miss the idea in the mind of the speaker which he is trying to verbalize through the medium of language.

Person deixies refer to the expressions used in linguistic communication to refer to individual person. Deixies in this category include: I, you, we, he, she, they, etc. Yule (1996:59) observes that as simple as the expressions employed in person deixies appear, their complexities actually are disguised. This is because in conversational situation, I is equal to you, and you is equal to I. In other words, as the conversation turn progresses the initial person identified as 'l' becomes 'you' and vice versa. 'Somebody/someone' is in the category of person deixies. Thus, interpreting 'somebody/someone' in the light of 'you' will become clear in the data analysis.

\section{Inference/ presupposition}

Another act involved in the analysis of discourse so as to make an association between what is said and what must be meant is inference and it is often used in connection with anaphora. Anaphora is subsequent mentioning of a formerly introduced item, as in these examples: 'He went to a shop', 'It was closed.' When shop was mentioned for the second time the pronoun 'it' was used to refer to it. Moreover, when people make use of such linguistic devices they necessarily make some assumptions about the knowledge of the speaker. Although some of the assumptions might be wrong, most of them are usually correct and they make the exchange of information smooth. What the producer of discourse correctly assumes to be known by the text's recipient is described as a presupposition (Wisniewski, 2007).

\section{Implicature}


Implicature, just like inference, is another way in which we use our background knowledge to arrive at interpretations of discourse. According to Yule (1996:111) an implicature is 'an additional conveyed meaning' in a text. Consider the following exchanges:

A: Are you coming for the naming ceremony this evening?

B: I am travelling right now, I won't come back until next week Friday.

B's statement may not be considered an answer, grammatically, since the simple answer required here is either Yes or No. B's answer, however, is not only a statement of a week's programme, it contains an implicature. Thus, utterances that seem unrelated superficially become interpretable once we know that they contain relevant information.

\section{Speech Acts}

Speech acts theory argues that when language is used, certain acts are being performed. Three types of acts which utterances can be said to perform are: a locutionary act - the act of saying something that makes sense in the language; 'consisting in a combination of a phonic act (production of actual noise), a phatic act (production of certain words in a certain syntactic order), and the rhetic act (communication of a specific message)' ( Halion, 2003 in Adetunji,2009); an illocutionary act - act of 'meaning' performed through the medium of language: warning, promising, requesting, stating, and so on; and a perlocutionary act - the effect the illocutionary act has on the listener: such as misleading, persuading, convincing, and so forth. A particular illocutionary act could be successful or not. The factors that determine whether a particular illocutionary act succeeds are termed felicity conditions or appropriacy conditions.

Based on the different views of speech act theorists, all utterances constitute speech acts of one kind or another (cf. Finch, 2000). Thus, taxonomies of speech act types provided by theorists vary in details. However, one of the most widely used, which is directly relevant to our data is that proposed by Searle (1969: 10-16), with all acts divided into five main types as follows:

1. Representatives (Assertives), which commit the speaker in varying degrees to the truth of the expressed proposition. These are acts describing situations. To Mey (2001:120) "These speech acts are assertions about a state of affairs in the world (hence they are also called 'assertives') and they carry the values 'true' or 'false'".

2. Directives, which are attempts with varying degrees of force to get the addressee to do something. These acts direct somebody to do something.

3. Commissives, which commit the speaker to some future course of action. According to Mey (2001:120121) 'like directives, commissives operate a change in the world by means of creating an obligation, however, this obligation is created in the speaker, not in the hearer, as in the case of the directive'.

4. Expressives, which express the psychological state of the speaker with respect to the proposition. Expressive acts simply express the feelings/inner state of the speaker.

5. Declaratives, which effect immediate changes in the institutional state of affairs. The declarative act must, however, meet the felicity conditions to be effective.

Direct speech acts presented above provide a match between sentence meanings and speaker meaning. However, indirect speech act will not be so direct. For instance, it's cold in here can be categorized as declarative in line with the foregoing, whereas, its indirect meaning is 'can you close the window?' (cf. Dada, 2010). The present data is explored for both direct and indirect interpretations. What is more, 'the use of both direct and indirect speech acts is strongly connected with the linguistic concept of politeness' (Wisniewski, 2007). Politeness, according to Wisniewski, in the study of language is defined as showing awareness of other people's self-image by adjusting one's own speech style. Every person's self-image in pragmatics is called face and utterances presenting a threat to the interlocutor are known as facethreatening acts, while those which lessen the threats are called face saving acts. Thus, it is assumed in pragmatics that the use of indirect speech acts is characteristic of face saving acts.

\section{Aims and Objectives}

The main thrust of this paper is to investigate that aspect of meaning which is derived not from the formal properties of words and constructions but from the way in which utterances are used and how they relate to the context in which they are uttered (cf. Leech and Short, 1987). The study aims at facilitating an in-depth understanding of meaning in religion and religious motivated discourse.

The specific objectives of this study are:

(i) To examine the semantic content of these pronouns.

(ii) To systematically and objectively describe the pragmatic presuppositions behind the use of 'somebody/someone' in Christian religious discourse.

(iii) To invariably further confirm that pragmatics focuses on what speakers mean with their utterances rather than on what the words/phrases in those utterances might mean by themselves. 
This pragmatic approach to the study of meaning hopes to add to existing knowledge of how sociolinguistic variables aid the process of decoding the meaning encoded or shrouded in language.

\section{Methodology}

The study focuses on the pragmatic presuppositions of the indefinite pronouns 'somebody' and 'someone' in Christian religious ministration discourse. The discussion focused on in this paper features more prominently in Pentecostal churches in Nigeria or even else in the world, although a few ministers in the orthodox churches with Pentecostal orientation also use these pronouns on their congregations during religious ministrations.

As researchers in language use domiciled in South-western Nigeria and who attend church services regularly to elicit the type of information used for the study through an on-the-spot and unobstructive observation of language behaviours within the community (Nigeria) under study was not difficult. Apart from the data gathered from church services attended by the researcher, data were also gathered from sponsored Christian religious programmes on electronic media in the South-western part of Nigeria. Suffice it to say that English language is the major language of propagating the Christian religion either in Nigeria or the world over.

A major advantage of the methodology adopted here is that data drawn from these two sources, as far as the religious domain is concerned, show natural language use in society. The theoretical framework for this study is pragmatics. The communicative intentions of Christian ministers in their use of 'somebody' and 'someone' while ministering to the congregation in church services obviously extends beyond their use in ordinary everyday language. The study therefore calls for a pragmatic theory.

\section{Data Presentation and analysis}

The data here are divided into two groups, viz data I and data II for ease of reference during analysis.

\section{Data I}

i) Let somebody praise the Lord

ii) Somebody shout hallelujah

iii) Somebody say amen

iv) Is somebody happy here tonight?

v) Can somebody please stand up?

vi) Am I talking to somebody here tonight?

vii) There is somebody here, the Lord will beautify your life tonight.

viii) This programme is for someone who is crawling today, but who will fly tomorrow.

ix) Somebody is here whose heaven shall be opened today. Your heaven shall be opened today in Jesus' Name.

x) Beloved, somebody is here this morning who will not go back the same way. You are the one in Jesus' Name.

xi) Somebody is here, who will be blessed today, say hallelujah.

xii) I pray for somebody that that name people call you to describe you which does not glorify God shall change tonight in Jesus' Name.

xiii) I decree upon somebody that whatever is hindering your total deliverance shall die tonight.

xiv) I know that somebody is here and that within the next 24 hours, every veil covering your vision shall catch fire.

xv) Somebody needs a key here this morning to open the door the enemy has closed.

xvi) God is talking to somebody, this is your year, you shall get there in Jesus Name.

xvii) I pray for somebody that that name people call you to describe you which does not glorify God shall change tonight in Jesus' Name.

xviii) I decree upon somebody that whatever is hindering your total deliverance shall die tonight.

xix) I know that somebody is here and that within the next 24 hours, every veil covering your vision shall catch fire.

\section{Data II}

XX) There is somebody here, you know yourself, you are always oppressed in your dream. In fact, if you want me to come for you, I can, you are wearing a red shirt, God is visiting you right now. 
xxi) I am praying for someone here who is passing through the fire of the enemy, I pray the Holy Ghost fire will consume the fire of the enemy in Jesus' Name.

xxii) Somebody is here, you have been smelling death, tonight that death is cancelled.

xxiii) Somebody is here, you have been vomiting in your dream, now you have no strength, right now that attack is cancelled.

xxiv) Somebody is here the Lord says, 'I the Lord personally will direct your step this year.'

XXv) I heard a voice now, there is somebody here, the Lord says I will decorate you.

xxvi) Somebody is here, you were practically carried here because of heaviness. The enemy has stolen something from your life which is being restored now, the heaviness is gone now. If you are the one run quickly to the front, so that enemy will not put it back on you.

xxvii) Somebody is here, the power of God will fall on you now, the power of stagnancy shall be broken in the lives of 21 people. You may not be able to stand as the power of God falls on you now.

\section{Analysis}

The language or register of religion is different from the normal usage of English in vocabulary and style. The primary intention of any Gospel preacher in a worship service is to attract worshippers (i.e. seekers of God) to God and to increase the fold (kingdom) of God. Hence, language use in religion, like that of advertisement, is invariably persuasive. Very often, as evident in this study, persuasion is achieved by means of 'somebody' and 'someone'. This discussion of the meaning of 'somebody' and 'someone' in Christian religious discourse will revolve round stylistic interpretation, semantic interpretation and the pragmatic interpretation.

\section{Stylistic interpretation}

An examination of data I, reveals that 'somebody shout hallelujah' is a command. 'Can somebody please stand up?' is a rhetorical question while 'there is somebody here, the Lord will beautify your life tonight' is a statement. Data I (vii-xix) are not only statements; they are prophetic statements which do occur from time to time in evangelical gatherings. However, examples in data II are revelational statements (known as word of knowledge in the Christendom) that must be witnessed in any gatherings of true believers any time they are under prophetic unction.

Indeed, a good writer/speaker is sensitive to the need to adjust relevant parts of his sentences/utterances to meet certain stylistic and/or pragmatic requirements of the context of situation. Thus, the stylistic motivation for the employment of words like 'somebody' and 'someone' in English religious ministrations is because with these pronouns the preacher easily creates imperative structures without sounding offensive. 'Somebody shout hallelujah' for instance, is a mild command used to prompt action which is the shouting of hallelujah. Through the use of 'somebody' and 'someone', nobody's name is mentioned. Hence, it becomes very difficult even when the referent is known by everyone in the congregation to take offence. Besides, the use of these pronouns affords the individual concerned the latitude to react either positively or negatively to such an utterance. Therefore, in order to sound polite while commanding, the pronoun 'somebody' is usually employed to refer to different individuals in such a gathering. Besides, imperative structures like these ones are sometimes preferred during church services because they are persuasive and appealing to the congregation.

In sum, the use of 'somebody' and 'someone' in Christian religious ministration in English affords preachers the opportunity to define themselves stylistically in this context. What is more, the use of these pronouns has become a popular style and a defining feature of that variety of language. In style usage there is creativity. Thus, the creative use of these pronouns by gospel preachers in various sentence positions has resulted into sentence types such as commands, questions and statements, thereby enriching language use in Christian religious discourse.

\section{Semantic interpretation}

In grammar or semantics, 'somebody' or 'someone' means just one person, that is, a faceless individual 'Somebody' and 'someone' are indefinite pronouns in the category of 'anybody'. 'everybody', 'anyone', 'everyone' and even 'all' with all having no specific referents. Again, grammatically speaking, these pronouns are in the category of person deitic pronouns. That is, these are words employed for linguistic pointing. Another grammatical point very germane to our discussion here is that 'somebody' or 'someone' has 'you' as its anaphor any time the discourse is long enough to accommodate more than one or more subjects as in examples (xvi), (xvii),(xviii). True to type 'you' is ambivalent in meaning with either a singular or plural meaning depending on its context.

At this juncture, it must be stated that 'somebody' and 'someone' as used in the examples designated as data II carry their semantic interpretations intact in that the preacher's communicative intention in this context means 'one person' i.e. that very person having the particular challenge being identified by the word of knowledge, a special gift of the Holy Spirit. Although, two or more people may still come forward for prayers in this instance, the fact remains that the revelation is actually meant for few people, if not just one person. Thus, 'somebody' or 'someone' could mean one person or the whole congregation in the context of church worship services. This is so because 'somebody' has 'you' as its anaphora, even in grammar, and both work as 'you' (singular) and 'you' (plural) depending on its physical context of use. Indeed, any 
time 'somebody/someone' is used to refer to specific cases, then the singular meaning of 'one person' is also required here since the whole congregation cannot be under that particular yoke.

\section{Pragmatic interpretation}

Though more may be involved in the meaning of 'somebody/someone' when used by preachers during sermon, the primary reference here pragmatically speaking is every member of the congregation. Thus, utterances as contained in data I are uttered to refer to every member of the congregation since these are prayers, prophecies, rhetorical questions (that is, statements turned inside out) meant for every member of the congregation. Pragmatically or stylistically, the use of 'somebody' or 'someone' in these texts implies 'everybody' in that whoever has left his/her home for the worship service ought to have made up his/her mind for a serious business. Hence, 'somebody' in this context must be 'me or everyone else' in the congregation. Thus, 'somebody' becomes the appropriate use of an address system that integrates everybody into the discourse.

To fully understand the nature of our pragmatic inquiry here we refer to Adegoju (2002:26) as follows:

The use of indefinite pronouns in ordinary everyday language has shown that the audience or addressees that any of the indefinite pronouns is directed at usually dodge the responsibility assigned. Chief among these pronouns are 'someone', 'somebody', 'anyone',

and 'anybody'. This is why in normal interaction processes, it is commonplace that 'everybody's job is nobody's job' because almost everyone in the audience assigned the responsibility would normally dodge it, presuming that someone or somebody else could carry it out.

It is however noteworthy that the use of 'somebody' and 'someone' in religious circles has been attracting wild responses (thunderous shouts of amen) from the congregation. Invariably, the simple fact that 'in everyday language 'someone' or 'somebody' metamorphoses into 'nobody' whereas in Christian ministration discourse, 'someone' of 'somebody' coalesces with 'everybody' (cf.Adegoju 2002:21) indicates that these pronouns carry different meanings in religious discourse from their meanings in grammar. Thus, the semantic interpretation of these pronouns must be abandoned at this stage for the pragmatic motivation for the employment of these words in Christian religious discourse to come alive.

The pragmatic presuppositions behind the use of 'somebody' and 'someone' by Christian ministers in the context of church services will be explained here using Searle's (1969) and Lawal's (2003) model of pragmatics.

\section{The speech act analysis}

The speech act type associated with the use of 'somebody/someone' in these utterances is either a directive act or a declarative act. The indirect questions e.g. 'Can somebody shout hallelujah?' were used as directive acts to sound polite while commanding the congregation. The declarative structures e.g. 'somebody here is having headache, the problem is now being removed' were used as 'assertive' acts of 'stating'.

\section{Contexts/Competencies}

a). Linguistic: These pronouns are contained in simple sentences requires only basic competence in English grammar. The structures normally carry 'you' as the anaphora of these pronouns.

b). Situational : The topic of discourse here is always on the gospel of our Lord Jesus Christ and the benefits of His redemptive work on the cross of Calvary which include: healing, salvation, deliverance, provision, miracles and lots more. In short, gospel preachers preach generally on God's goodness to mankind. The setting always involves that of a Preacher and the congregation in a church or any building or location designated for the purpose of preaching sermons.

c). Psychological: the preacher preaches about what God can do in the life of the listeners and the need to respond to His invitation to all of us to come to Him. His message as the preacher is expected to strengthen the faith of members of the congregation to receive blessings abundantly from God, that is especially as he prays for them. Invariably, the onus is on the preacher to create an environment where members of the congregation can breathe the oxygen of salvation, healing, miracles, deliverance and so on. Thus, the preacher strives at all cost to prescribe the gospel solution as the panacea to the various problems of humanity.

d). Social: A relationship of father and 'little children' in the faith exists here between the preacher and members of the congregation. The preacher knows God better, hence, he labours passionately through his sermon to make his listeners know God in a way comparable to his own. He therefore preaches out of love, passion and duty. These necessities influence his style and use of language. To get across the message of God effectively, he must be polite, this he knows, hence the need to say 'somebody is here ...' most times.

e). Socio-Cultural: The text known today as the Bible was originally addressed to the Christians in Bible days, especially the Jews. The Scriptures, no doubt, has a timeless universal application. No wonder, every preacher capitalizes on this so as to make his trade prosper in his hands.

f). The Cosmological Context: The totality of the cosmological context (i.e. world-view) which is responsible for this utterance is a universalist, anti-racist conviction which the speaker deploys all his intellectual, linguistic and creative resources to defend and promote. God's love for mankind, as recorded in John3:16, is not restricted to any one nation, 
race/ethnic group/culture or even to any spiritual elite. What is more, the transformational power of the word of God is something evident in the world right from Bible days up till today.

Having discussed the context of situation behind the use of these pronouns, in what follows, we present in details the pragmatic presuppositions motivating the use of 'somebody/someone' by Christian ministers in Churches. As stated already expressions such as 'somebody shout hallelujah', 'somebody clap for Jesus' are mild commands serving the directive function. Thus, they are usually used to prompt the kind of actions expressed by the (performative) verbs of these utterances. In order to sound polite while commanding, the pronoun 'somebody' is usually selected by the preacher. Thus, 'somebody/someone', an indefinite/impersonal pronoun is employed in this context in place of personal pronouns and proper names because of the need to remain polite and maintain the self-esteem of the addressee. It can be inferred from this use, as stated earlier on, that the target group or the intended speaker meaning is made up of every member of the congregation. The use of impersonal pronoun 'somebody/someone' for the second pronoun 'you' could be to politely suppress a direct accusation, invariably turning such utterances to indirect accusations. Language users employ indirect speech acts so as not to infringe on the hearer's face. Direct addresses tend to appear impolite and face threatening. Hence, the need to adopt an utterance with the facing act.

Again, the use of 'somebody/someone' in conjunction with 'you' (personal pronoun) in some of the examples above makes the preacher's language to sound warm and friendly. They help to narrow the gap between the speaker and the listener and make the message more appealing. The use of 'somebody' and the personal pronoun 'you' as the anaphora in prophetic utterances makes the listener to feel that he/she is the particular person the speaker cares about and is eager to help. No wonder the wild shouts of 'amen' that accompanies the issuance of such decrees and prophetic prayers. Further still, to say that 'there is somebody here tonight whose cup will flow to overflow' means that the prophecy is for at least one person and even if the prophecy is not directly for the other people in the congregation, as many as are willing can connect with the overflow of the prophecy. This way, the use of these pronouns ensures congregational participation.

In furtherance of the 'politeness' theme, to politely suppress any direct accusation from any member of the congregation, the preacher employs the impersonal pronoun 'somebody/someone' in place of proper names especially when this speaker is not too sure who the referent of his utterance is. To quote our Pastor, while ministering recently in a Sunday service, he said, 'when God says, "there is someone here", someone may be one million people!' Again on this, we quote Hagin (2006: 185-186):

Some people think prophets know everything. But that's not the case. We as ministers don't know everything, either. All we know is what God tells us. Often during a service, God has told me there's someone present He wants to minister to. A few times He has also told me who it is. But that's the exception, not the rule. Samuel knew only what God had told him - that one of Jesse's sons would be next king in Israel. Why doesn't God tell us the whole story all at once? Because if He were to tell us everything about our situations, we'd be walking by sight and not by faith. And if we don't walk by faith, we can't please Him (Heb. 11:6). That's the reason He didn't tell Samuel at the start which of Jesse's sons to anoint as king.

Kenneth Hagin (2006:186) gave another example that is very germane to our analysis here as follows:

The pianist in our church in Farmersville had a tumor in her left lung .... She hadn't asked us to pray, But as I concluded the service one Sunday morning, the Lord told me, "There's a woman here I want to heal before you go today." Now if I had hesitated, I would have thought, Well, if there's a woman He wants to heal, doesn't He Know who it is? I would have dismissed the service and missed God. And this dear sister might not have received her healing. Before I had time to think, I said, "The Lord wants to heal a woman here this morning." A lady stepped out of the congregation and started walking toward the front. In my spirit... I heard, "She's not the one." So I said to this woman, "Sister, you're not the one He's talking about. But come on down, because healing belongs to you. I'll pray for you and lay my hands on you." About that time, the pianist stepped out. The Holy Spirit said to me, "She's the one." So I laid hands on her and prayed. The following Tuesday, she went back to the hospital for treatments. After a few X-rays, the doctors told her the tumor was completely gone!

The foregoing strongly attests to the fact that genuine, that is, Spirit-filled ministers of God use 'somebody/someone' in ministrations (1) based on what they heard from God. In other words, 'somebody is here ...' is directly from God; (2) to allow the recipients of the miracles manifest faith in the God of miracles. That is, the recipient himself/herself needs to cooperate with the Holy Spirit by identifying himself/herself through self volition. In this regard, Jesus Himself who knows all things in Luke 8:46 used 'somebody' to refer to the woman with the issue of blood in spite of the fact that the miracle had already taken place. Jesus said, 'somebody hath touched me: I perceived that virtue is gone out of me.' Thus, by this act, Jesus Himself teaches His followers the necessity to have beneficiaries of God's blessings identify themselves by their own volition. Invariably, modern day preachers have simply identified with Jesus in their use of 'somebody/someone' to refer to anybody who has experienced or will experience the healing power of God.

Finally on this, the Bible identifies unbelief as one of the very reasons why miracles, signs and wonders are often lacking in the Christian community. Unbelief, a form of sin, hinders the prayers of believers and blocks the healing power of God from manifesting in the congregation. Thus, one way of solving this problem is to employ 'somebody/someone' a pronoun like 'you' which is indefinite, polite and all-encompassing. The use of 'somebody' implies that God is not partial, not a respecter of persons, hence, the onus rests on the hearer of such a message to key into the move of the Spirit who is not discriminatory. 


\section{Conclusion}

This is an exploration into the pragmatic presuppositions behind the use of 'somebody' and 'someone' in Christian church services in Nigeria and indeed all over the world. The paper has revealed that no one can water down or trivialize any experience in the house of God. Christians all over the world usually gather together for a spiritual purpose. To the uninitiated, the reason behind the use of 'somebody' or 'someone' in Christian churches is trivial like to create humour and excitement. Granted that the use of these pronouns is to create involvement, over and above this is the fact that that is the very language of God Himself. Indeed, a burdened heart needs no entertainment or excitement of this sort. In fact, such a fellow is desperately looking for a solution to his/her problem which can only be granted by God.

The foregoing has once more brought to the fore the merit of the campaign that a writer/speaker needs good training not only in the area of grammatical competence but also in that of communicative competence of the language with which he works. Familiarity with the grammar and even beyond grammar, pragmatics of the language with which he works is an indispensable qualification of an aspiring or practising writer/speaker. We are stressing this point in favour of flawless constructions of all functional structures of English utterances by users.

\section{References}

Abiodun, M.A. (1992) 'On the Restricted Spread of the honorific Pronoun in Yoruba: A Case Study of Ondo, Owo and Oyi Dialects African Languages and Cultures 5.2. 101-111.

Abiodun, M.A. (1999) 'Name avoidance in Yoruba' OLOTA : Journal of African Studies 3.1. 24-29.

Adegoju, A. (2001) 'On the fluidity of Address system: The Example of Honorific Pronouns in Yoruba' Obitun: Journal of the Humanities Vol.3 No.1 pp.25-33.

Adegoju, A. (2002) 'The pragmatics of 'someone' and 'somebody' in Christian Ministration Discourse ' CONTEXT: Journal of Social and Cultural Studies Vol.5.2. pp.25-33.

Adetugbo, A. (1969) 'The pronoun in Yoruba: Its functions in three dialects'. Paper presented at the 8e Congres de la Societe Linguistique de L'Afrique Occidentale, Abijan.

Adetunji, A. (2009) 'Acts in the Second Inaugural Address of Nigeria's President Olusegun Obasanjo and American President George Bush' In Odebunmi, A., Arua, E.A. and Arimi, S. (eds.) Lnaguage Gender and Politics: A Festschrift for Yisa Kehinde Yusuf Lagos: Concept Publications Ltd 275-296.

.Akindele, F. (1990) 'A Sociolinguistic Analysis of Yoruba Greetings' African Languages and Cultures 3:1-14.

Akinnaso, F. N. (1980) 'The Sociolinguistic Basis of Yoruba Personal names' Anthropological Linguistics Vol. 22.7. 275-304.

Brown, R. and A. Gilman (1968) 'The Pronouns of Power and Solidarity' In J.A. Fishman (ed.) Readings in the Sociology of Language Hague: Mouton \& co. N.V. Publishers. 252-275.

Brown, R. and Ford, M. (1961) 'Address in American English' Journal of Abnormal and Social Psychology 62: $375-85$. Reprinted in Hymes 1964:234-44.

Dada, S.A. (2010) 'A Speech Act Analysis of Slogans of Telecoms Companies in Nigeria'. In Kuupole, D.D. and Bariki, I. (eds.) Applied Social Dimensions of Language Use and Teaching in West Africa. Festschrift in Honour of Professor Tunde Ajiboye. Ghana: The University Press. 52-62.

Ekundayo, S.A. (1977) 'Restrictions on Personal Name Sentences in the Yoruba Noun Phrase' African Linguistics 19. 5577.

Evans, V. and Green, M. (2006) Cognitive Linguistics: An Introduction Edinburgh: Edinburgh University Press.

Finch, G. (2000) Linguistic Terms and Concepts New York: Palgrave Macmillian

Griffiths, P. (2006) Introduction to Semantics and Pragmatics Edinburgh: Edinburgh University Press.

Hagin, K.E. (2003) How You Can Be Led by the Spirit of God USA: Kenneth Hagin Ministries, Inc.

Halliday, M.A.K. and Hassan, R. (1976) Cohesion in English London: Longman

Ikotun, R. O. (2003) ljesa Pronouns in the Sociocultural Context Unpublished Ph.D Thesis. University of Ibadan, Ibadan, Nigeria.

Ikotun, R.O. (2009) 'ljesa Plural Pronouns in the Socio-cultural Context. UNAD Studies in Language and Literature Vol.3.1. 35-45.

Ikotun, R.O. (2010a) 'The Social Use of Yoruba Personal Names. Names 58.3. 169-186.

Ikotun, R.O. (2010b) 'A Sociolinguistic Analysis of Vowel Lengthening in Yoruba' Journal of West African Languages. 37.2.3-11.

Kempson, R. (1975) Presupposition and the Delimitation of Semantics Cambridge: Cambridge University Press. 
Lambert, W. and Tucker, G.R. (1976) Tu, vous, usted: A socio-psychological study of address patterns Rowley, M A: Newbury House.

Lawal, A. (2003) 'Pragmatics in Stylistics: A Speech Act Analysis of Soyinka's 'Telephone Conversation'. In A. Lawal (ed.) Stylistics in Theory and Practice llorin: Paragon Books pp.150-173.

Leech, G.N. and Short, M.H. (1987) Style in Fiction: A Linguistic Introduction to English Prose London: Longman.

Leech, G. and J. Thomas (1990) 'Language Meaning and Context: Pragmatics' In Collin, N.E. (ed.) An Encyclopedia of Language. London: Routledge 173-201

Levinson, S.C. (1983) Pragmatics Cambridge; Cambridge University Press.

Low, R. (2003) 'The Hidden Path of Semantic Context within Pragmatic Context: The Definite Article 'the'.' Abstract submitted to the International workshop on current research on the semantics-pragmatics interface. Michigan State University. pp.1-4.

Mey, J. (2001) Pragmatics: An Introduction USA : Blackwell Publishers

Oha, O. (1994) Language in War Situation: A Stylistic Study of Selected War Speeches of Gowon and Ojukwu. An Unpublished Ph.D Thesis. University of Ibadan.

Paulston, C. B. (1975) 'Language and social class: Pronouns of address in Swedish. (Working papers in sociolinguistics, 29) Austin, TX: South-West educational Development.

Oyetade, S.O. (1995) 'A Sociolinguistic analysis of address forms in Yoruba, Language in Society 24: 4, 515-535.

Searle, J. (1969) Speech Acts London: Cambridge University Press.

Sperber, D. and Wilson, D. (1981) 'Pragmatics' In Cognition 10: 281-286.

Stalnaker, R. (1972) 'Pragmatics' In D. Davidson and Harman, G. (eds.) Semantics of Natural Language Lorrocht, 380397.

Wisnieswki, K. (2007) available at wisniewski Jezyk angielski online.htm

Yule, G. (1996) Pragmatics London: Oxford University Press.

Yule, G. (1999) The Study of Language Cambridge: Cambridge University Press. 